\title{
In vitro propagation, DNA content and essential oil composition of Teucrium scorodonia L. ssp. scorodonia
}

\author{
Joanna Makowczyńska ${ }^{1}$ Elwira Sliwinska ${ }^{2}$ - Danuta Kalemba ${ }^{3} \cdot$ Ewelina Piątczak $^{1}$. \\ Halina Wysokińska ${ }^{1}$
}

Received: 19 February 2016/Accepted: 12 June 2016/Published online: 23 June 2016

(c) The Author(s) 2016. This article is published with open access at Springerlink.com

\begin{abstract}
Teucrium scorodonia ssp. scorodonia is a valuable medicinal plant. It is rare in Poland, therefore availability of raw material is limited and an effective method of producing in vitro-derived plants for pharmaceutical reasons would be desirable. However, the protocol for micropropagation of this species has not been developed yet. Here, its regeneration ability on media supplemented with different growth regulators was evaluated using shoot tip and nodal segment explants. Murashige and Skoog (MS; Physiol Plant 15:473-497, 1962. doi:10.1111/j.13993054.1962.tb08052.x) medium supplemented with indole3 -acetic acid (IAA) $\left(0.1 \mathrm{mg} \mathrm{L}^{-1}\right)$ and 6-benzyladenine (BA) $\left(2 \mathrm{mg} \mathrm{L}^{-1}\right)$ was the best for multiple shoot induction, resulting on average in about 7 and 8 axillary shoots per shoot tip and nodal explant, respectively, within 5 weeks. Flow cytometric analysis revealed that most of the in vitrodeveloped shoots of $T$. scorodonia possessed similar nuclear DNA content as seedlings (about $2.1 \mathrm{pg} / 2 \mathrm{C}$ ). In vitro rooting of shoots was achieved at $100 \%$ efficiency on MS medium without growth regulators or containing
\end{abstract}

Electronic supplementary material The online version of this article (doi:10.1007/s11240-016-1024-3) contains supplementary material, which is available to authorized users.

Joanna Makowczyńska

joanna.makowczynska@umed.lodz.pl

1 Department of Biology and Pharmaceutical Botany, Medical University of Lodz, ul., Muszynskiego 1, 90-151 Lodz, Poland

2 Laboratory of Molecular Biology and Cytometry, Department of Plant Genetics, Physiology and Biotechnology, UTP University of Science and Technology, Al. Prof. S. Kaliskiego 7, 85-789 Bydgoszcz, Poland

3 Institute of General Food Chemistry, Lodz University of Technology, ul. Stefanowskiego 4/10, 90-924 Lodz, Poland auxin. The addition of auxin, IAA, indole-3-butyric acid (IBA) or $\alpha$-naphthaleneacetic acid (NAA) led to an increase in the number of roots. Rooted plantlets were transferred into ex vitro conditions and further grown in the field, where they matured and flowered. The essential oils from aerial parts of the in vitro-originated plants and their seed-derived counterpart were isolated and analyzed by gas chromatography-mass spectrometry (GC-MS). In the oils, 84 components were identified. Although the essential oils from the micropropagated plants and the seed-derived plants were qualitatively similar, quantitative differences were found.

Keywords Micropropagation - Cytokinins - Flow cytometry · Genome size · Essential oils · Teucrium scorodonia

\section{Introduction}

The genus Teucrium includes over 300 species spread all over the world, but most of them are found in the Mediterranean basin. Many species of Teucrium possess different biological properties, such as antibacterial, antifungal, anti-inflammatory, antioxidant, antipyretic, diuretic and hypoglycemic activities, and they are used in traditional medicine (Ulubelen et al. 2000; Kovacevic et al. 2001; Maccioni et al. 2007; Küçük et al. 2008; Djabou et al. 2013). The aromatic plants are also used in the production of flavoured wines and beers, bitters and liqueurs (Djabou et al. 2012; Maccioni et al. 2007).

In the Polish flora, the genus Teucrium is represented by five species (Mirek et al. 2002); among which, T. scorodonia ssp. scorodonia (herein referred to as $T$. scorodonia) has been identified. In Poland, T. scorodonia is a 
rare plant and it has been found only in Western Pomerania and Lower Silesia. It is a perennial shrub, about $30-50 \mathrm{~cm}$ high, characterized by greenish-yellow flowers with a corolla about twice as long as the calyx, which has short hairs and few or no glands (Tutin et al. 1972).

The leaves and flowers of $T$. scorodonia are known for their astringent, antiseptic, expectorant and digestion-improving properties (Maccioni et al. 2007). In some regions, the plant is used as a hop substitute for flavoring beer. The characteristics of $T$. scorodonia are mainly associated with the presence of essential oils that are rich in sesquiterpene hydrocarbons (Maccioni et al. 2007). Particularly important components of this group of metabolites are $\beta$-caryophyllene and germacrene D. $\beta$ caryophyllene is known to be a selective agonist of cannabinoid receptor type- $2\left(\mathrm{CB}_{2}\right)$. The receptors may be targeted in the treatment of depression and anxiety (Guimarães-Santos et al. 2012; Bahi et al. 2014). Moreover, caryophyllene inhibits the growth of Trypanosoma cruzi and Leishmania brasiliensis parasites (Leite et al. 2013). Germacrene D demonstrates antifungal, antimicrobial and insecticidal properties (Picaud et al. 2006; Noge and Becerra 2009; Zarai et al. 2011). Apart from the essential oil, other secondary metabolites such as diterpenoids, caffeic acid, ursolic acid, and flavonoids were identified in T. scorodonia (Marco et al. 1982, 1983; Rodriguez-Hanh et al. 1994; Valant-Vetschera et al. 2003).

Micropropagation is a common method for the rapid and large-scale production of many medicinal plant species, including some Teucrium species, such as T. polium (AlQudah et al. 2011), T. fruticans (Frabetti et al. 2009), and T. stocksianum (Bouhouche and Ksiksi 2007). However, to the best of our knowledge, in vitro propagation of $T$. scorodonia has not been reported before. The aim of the present research was to develop an effective protocol for micropropagation of this species.

The study examines the morphogenic responses of shoot tips and nodal explants of $T$. scorodonia to various cytokinins: 6-benzyladenine (BA), zeatin (ZEA), 6-furfurylaminopurine (kinetin, KIN), and thidiazuron (TDZ); as well as the effect of various auxins: indole-3-acetic acid (IAA), indole-3-butyric acid (IBA), and $\alpha$-naphthaleneacetic acid (NAA), on the rooting of the obtained shoots. Although production of shoots directly from meristematic structures ensures high genetic stability, culture conditions, such as the presence of exogenous growth regulators, can lead to somaclonal variation (Bairu et al. 2011; Matsuda et al. 2014; Lebedev and Shestibratov 2016). Somaclonal variation can affect the quality and quantity of secondary metabolites produced by micropropagated plants (OksmanCaldentey 2014; Skała et al. 2015). Therefore, flow cytometry was used to compare the nuclear DNA content in T. scorodonia seedlings and shoots multiplied under in vitro conditions. Moreover, gas chromatography coupled with mass spectrometry (GC-MS) was employed to study the composition of hydrodistilled essential oils from aerial parts of $T$. scorodonia micropropagated plants. The results were compared with the respective plants derived from seeds.

\section{Materials and methods}

\section{Shoot culture establishment}

Teucrium scorodonia seeds obtained from the Botanical Garden of Lodz (Poland) were surface sterilized in $2 \%$ sodium hypochlorite solution for $10 \mathrm{~min}$, washed three times with sterile distilled water for $15 \mathrm{~min}$ each, then placed on MS agar $(0.7 \%$ w/v SIGMA, Aldrich) medium containing $3 \%$ sucrose, gibberellic acid $\left(\mathrm{GA}_{3}\right)\left(1 \mathrm{mg} \mathrm{L}^{-1}\right)$ and kinetin (KIN) $\left(0.2 \mathrm{mg} \mathrm{L}^{-1}\right)$ for germination. Shoot tips $(0.5 \mathrm{~cm}$ in length) from 35 -day-old seedlings were excised and transferred onto MS agar medium supplemented with $0.1 \mathrm{mg} \mathrm{L}^{-1}$ IAA and $0.2 \mathrm{mg} \mathrm{L}^{-1} \mathrm{BA}$. The cultures were subcultured every 42 days. They were grown at $26 \pm 2{ }^{\circ} \mathrm{C}$ in a $16 \mathrm{~h}$ photoperiod. Light at intensity of $40 \mu \mathrm{mol} \mathrm{m} \mathrm{m}^{-2} \mathrm{~s}^{-1}$ was provided by cool white fluorescent lamps (POLAMP, Poland).

\section{Effect of cytokinins on shoot multiplication}

Two types of explants: shoots tips $(0.5 \mathrm{~cm}$ in length) and nodal segments $(0.5 \mathrm{~cm}$ in length, having two axillary buds) from in vitro cultured shoots (obtained as described above) were transferred onto MS agar medium supplemented with $0.1 \mathrm{mg} \mathrm{L}^{-1}$ IAA and different concentrations of BA, ZEA, KIN $\left(0.2,0.5,1,2 \mathrm{mg} \mathrm{L}^{-1}\right)$ or TDZ $(0.02$, $0.05,0.1,0.2 \mathrm{mg} \mathrm{L}^{-1}$ ). Two control media were applied: (1) MS medium without growth regulator, and (2) MS medium supplemented with auxin IAA only $\left(0.1 \mathrm{mg} \mathrm{L}^{-1}\right)$. After 35 days the number of shoots per explant, shoot length, and frequency of hyperhydricity were determined.

\section{Root development, plantlet acclimatization, and plant cultivation}

After 35 days, excised axillary shoots derived from shoot tips and nodal segments were transferred onto MS agar medium, either without plant growth regulators or supplemented with auxin (IAA, IBA or NAA) at concentration of 0.1 or $0.5 \mathrm{mg} \mathrm{L}^{-1}$. The shoots were rooted within 42 days, when the number of roots per shoot was recorded.

The in vitro-derived rooted shoots (42 days old) were transplanted into pots $(10 \mathrm{~cm}$ in diameter $)$ containing a 
sterilized mixture of soil, sand and peat $(4: 3: 3 \mathrm{v} / \mathrm{v} / \mathrm{v})$ and placed in the greenhouse $\left(26 \pm 2{ }^{\circ} \mathrm{C}\right.$, natural light). To ensure high humidity, the plants were covered with glass beakers, which were removed after 14 days of acclimatization. Sixty days after transplanting the plantlets to the pots, the survival rate was assessed and after another successive 30 days, the plants were moved to the field. The ex vitro plants were propagated from seeds originated from the same source as those used for shoot culture initiation. They were grown in the greenhouse for 90 days and then were moved to the field. All the plants were grown in the field (compost substrate, sunny stand) at the Department of Pharmacognosy Medicinal Plant Garden, Medical University of Lodz, Poland, where they exhibited normal development and reached the flowering stage in the second year of cultivation. The aerial parts were collected at the flowering stage and dried at $25{ }^{\circ} \mathrm{C}$. The plants were positively identified as $T$. scorodonia spp. scorodonia according to Flora Europaea (Tutin et al. 1972). Voucher specimens ( $\mathrm{N}^{\circ} 5$ and 6) were deposited in the Department of Biology and Pharmaceutical Botany, Medical University of Lodz.

\section{Genome size estimation}

Flow cytometry was used to check the stability of genome size in in vitro-derived shoots of $T$. scorodonia. The leaves of 35-day-old seedlings, and of shoots multiplied on MS media with BA, KIN or TDZ were used for estimation of nuclear DNA content. Vicia villosa 'Minikowska' ( $2 \mathrm{C}=3.32 \mathrm{pg}$; Dzialuk et al. 2007) served as an internal standard. Samples were prepared as previously described (Thiem and Sliwinska 2003), using Galbraith's buffer (Galbraith et al. 1983), supplemented with propidium iodide (PI; $50 \mu \mathrm{g} \mathrm{mL}^{-1}$ ), ribonuclease A $\left(50 \mu \mathrm{g} \mathrm{mL}^{-1}\right.$ ), and polyvinylpyrrolidone (PVP-10; $1 \%$ w/v). Nuclear DNA content was estimated by a CyFlow SL Green (Partec GmbH, Münster, Germany) flow cytometer, on five plants from each combination. For each sample, DNA content in 3000-6000 nuclei was measured, using linear amplification. Histograms were evaluated using the FloMax program (Partec $\mathrm{GmbH}$, Münster, Germany). The coefficient of variation (CV) of the $\mathrm{G}_{0} / \mathrm{G}_{1}$ peak of T. scorodonia ranged between 3.5 and $6.4 \%$. Nuclear DNA content was calculated using the linear relationship between the ratio of the $2 \mathrm{C}$ peak positions of $T$. scorodonia/V. villosa on a histogram of fluorescence intensities.

\section{Isolation and analysis of essential oil}

For analysis of essential oils, the following plant material was selected: seed-derived plants (SP), two samples of in vitro derived plants obtained from shoot tips cultured on MS medium in the presence of $0.1 \mathrm{mg} \mathrm{L}^{-1}$ IAA, and one of the cytokinins: BA $\left(0.2 \mathrm{mg} \mathrm{L}^{-1}, \mathrm{~V}_{1} \mathrm{P}\right)$ or KIN $\left(0.5 \mathrm{mg} \mathrm{L}{ }^{-1}, \mathrm{~V}_{2} \mathrm{P}\right)$. All analyzed plants were grown in the field under the same conditions.

The essential oils of dried plant material $(50 \mathrm{~g})$ were obtained by hydrodistillation for $3 \mathrm{~h}$, according to European Pharmacopoeia 5.0 (2005), using Clevenger-type apparatus. After assessment of volume, the oils were collected in diethyl ether and dried over anhydrous sodium sulfate. Chemical composition of the essential oils was analyzed using GC-MS on a Trace GC Ultra apparatus (Thermo Electron Corporation, Milan, Italy) with FID and MS DSQ II detector after dilution in diethyl ether $(10 \mu \mathrm{L}$ in $1 \mathrm{~mL})$. Simultaneous GC-FID and MS analyses were performed using a MS-FID splitter (SGE, Analytical Science). Operating conditions were as follows: Apolar capillary column Rtx-1 ms (Restek), $60 \mathrm{~m} \times 0.25 \mathrm{~mm}$ i.d., film thickness $0.25 \mu \mathrm{m}$; temperature program, $50-310{ }^{\circ} \mathrm{C}$ at $2{ }^{\circ} \mathrm{C} / \mathrm{min}$; SSL injector temperature $280{ }^{\circ} \mathrm{C}$; FID temperature $300{ }^{\circ} \mathrm{C}$; split ratio 1:20; carrier gas helium at a regular pressure of $300 \mathrm{kPa}$. Mass spectra were acquired over the mass range 30-400 Da, ionization voltage $70 \mathrm{eV}$; ion source temperature $200{ }^{\circ} \mathrm{C}$. The identification of the components was based on a comparison of their mass spectra and relative retention indices with data stored in the NIST 98.1, Wiley 8th Ed. and MassFinder 4.1. libraries (Adams 2002). Retention indices (RI, apolar column) were determined with relation to a homologous series of alkanes $\left(\mathrm{C}_{8}-\mathrm{C}_{26}\right)$ under the same conditions with linear interpolation. Percentages were calculated from FID response without the use of correction factors.

\section{Statistical analysis}

Results are presented as the mean \pm standard error (SE). The shoot multiplication experiment was replicated three times in three subsequent treatments, through three successive passages. In total, 32-42 shoot tips and nodal explants were used per each cytokinin treatment. The rooting experiment was also performed in three replicates. The total number of 30 shoots derived from shoot tips and 30 shoots derived from nodal explants were raised for each treatment. The results presented in Figs. 1 and 2 were analyzed by the Kruskal-Wallis test to compare the means. The results were regarded as statistically significant at $P \leq 0.05$. The results of DNA content measurements were evaluated using the one-way analysis of variance (ANOVA) and Tukey's test at $P \leq 0.05$. All statistical analyses were performed using STATISTICA v. 12.5 (STATSoft) software. 

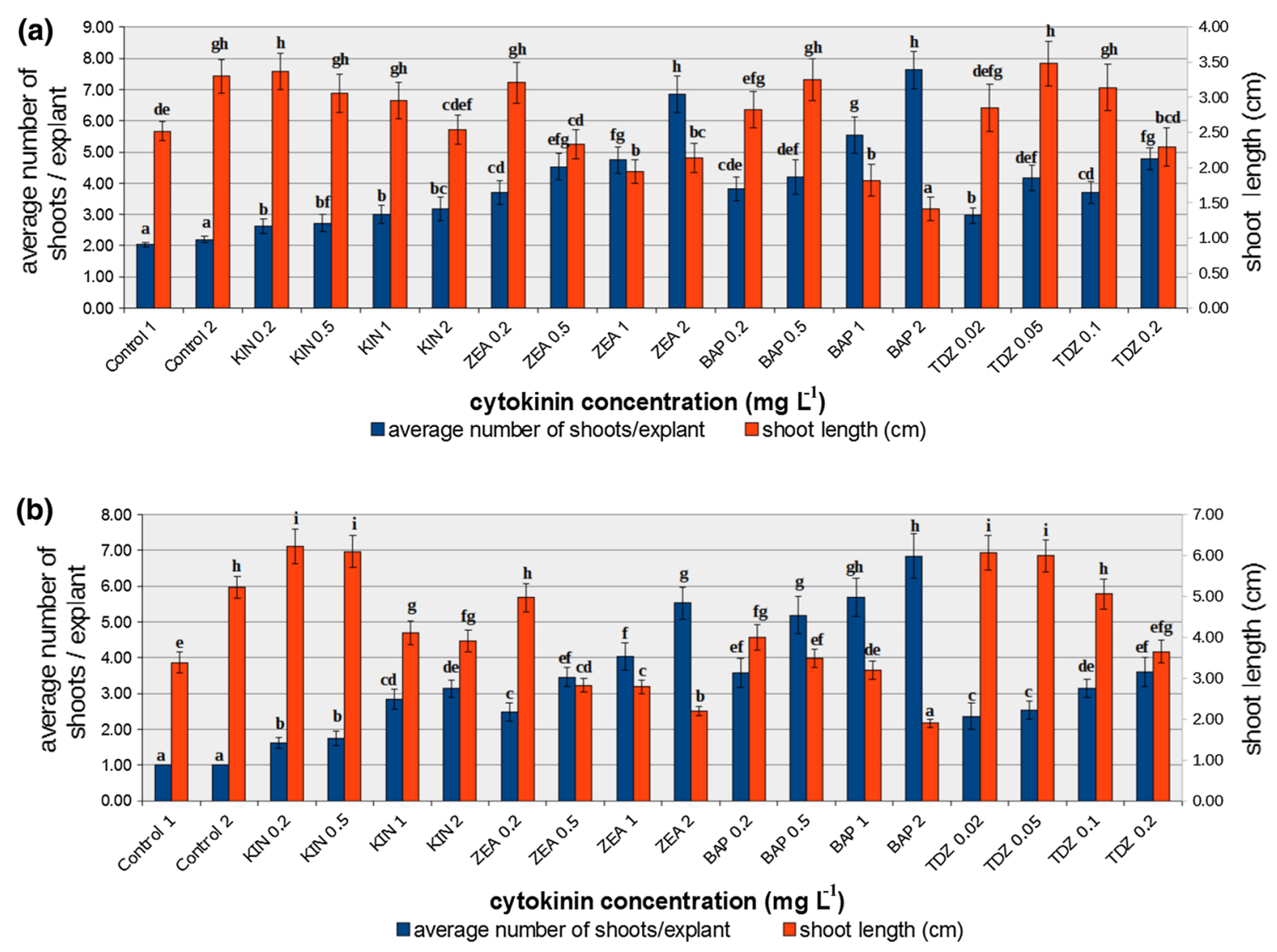

Fig. 1 Effect of different cytokinins on shoot multiplication from a nodal explants and $\mathbf{b}$ shoot tips of $T$. scorodonia after 35 days of culture on MS medium containing IAA $\left(0.1 \mathrm{mg} \mathrm{L}^{-1}\right)$. The values represent the means of three replicates. Means followed by the same letter at each parameter were not significantly different at $P \leq 0.05$ according to the Kruskal-Wallis test. Control $1-\mathrm{MS}$ medium without growth regulators; Control 2-MS medium supplemented only with IAA $\left(0.1 \mathrm{mg} \mathrm{L}^{-1}\right)$

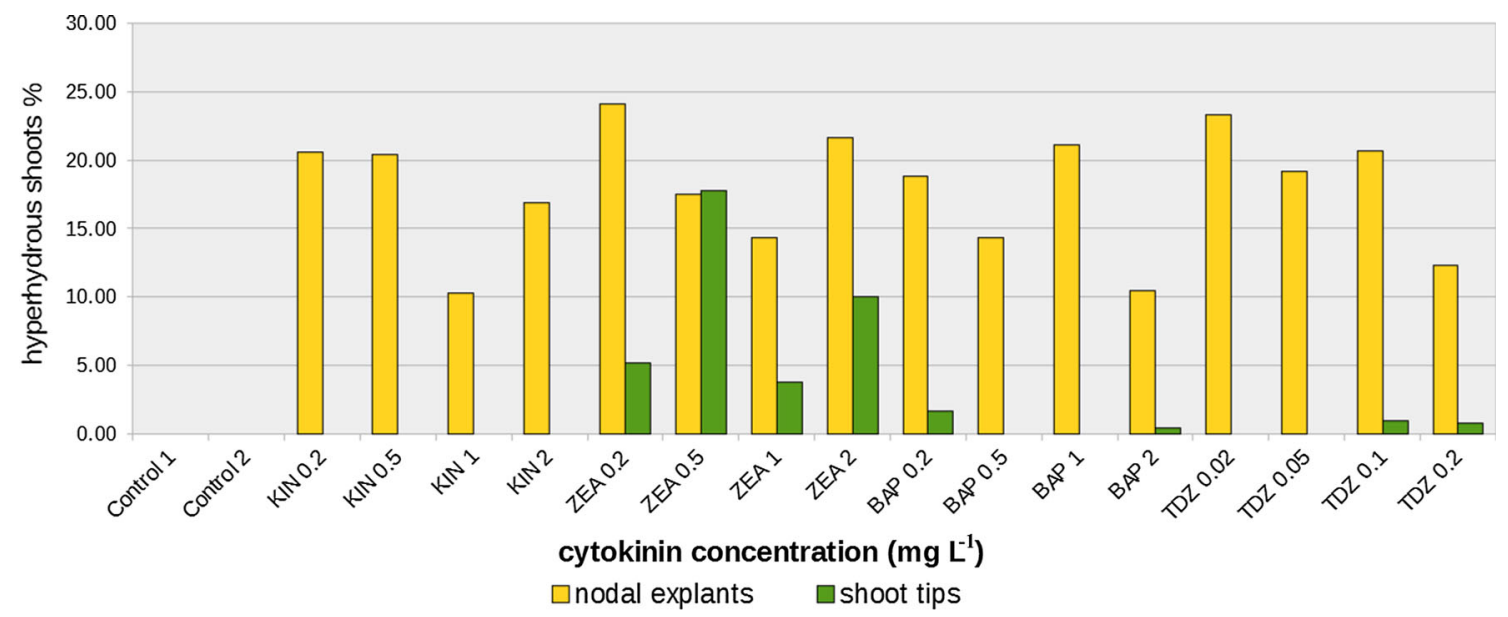

Fig. 2 Hyperhydricity (\%) of multiple shoots of T. scorodonia regenerated from nodal explants and shoot tips under different cytokinin concentrations (on MS medium with $0.1 \mathrm{mg} \mathrm{L}^{-1} \mathrm{IAA}$ ) 


\section{Results and discussion}

\section{Micropropagation of $T$. scorodonia}

No multiple shoot formation was observed when T. scorodonia shoot tip and nodal explants were cultured on MS medium without growth regulators or containing IAA $\left(0.1 \mathrm{mg} \mathrm{L}^{-1}\right)$ alone. One or two axillary shoots were developed from pre-existing buds (Fig. 1a, b). For development of multiple shoots the presence of cytokinin was required. After 5 weeks of culture on MS medium supplemented with $0.1 \mathrm{mg} \mathrm{L}^{-1} \mathrm{IAA}$ and BA, ZEA, KIN (0.2, $0.5,1$, and $\left.2 \mathrm{mg} \mathrm{L}^{-1}\right)$ or TDZ $(0.02,0.05,0.1$, and $0.2 \mathrm{mg} \mathrm{L}^{-1}$ ) all the shoot tips and $86-100 \%$ of the nodal segments developed axillary shoots without callus formation. It was observed that, in general, higher numbers of regenerated shoots per explants, and shorter average shoot lengths were observed in media with higher cytokinin concentrations (Fig. 1a, b).

The best multiplication results were recorded when nodal explants were cultured on medium containing $0.1 \mathrm{mg} \mathrm{L}^{-1}$ IAA and $2 \mathrm{mg} \mathrm{L}^{-1} \mathrm{BA}$ or $2 \mathrm{mg} \mathrm{L}^{-1} \mathrm{ZEA}$; mean shoot number was about 8 and 7 per explant, respectively (Fig. 1a). The elongation of shoots was significantly better on medium containing $2 \mathrm{mg} \mathrm{L}^{-1}$ ZEA (shoot length over $2 \mathrm{~cm}$ ) than in the presence of $2 \mathrm{mg} \mathrm{L}^{-1}$ BA (mean $1.4 \mathrm{~cm}$ ). However, hyperhydric shoots grown on medium supplemented with ZEA were more frequent than those on medium with BA (Fig. 2). Consequently, the number of good quality shoots (without hyperhydricity) with derived growth potential was lower in the presence of ZEA. Substituting BA with TDZ or KIN resulted in reduction of shoot multiplication. In the presence of TDZ at optimal concentration $\left(0.2 \mathrm{mg} \mathrm{L}^{-1}\right)$, fewer than 5 shoots per nodal explant were produced. The average length of the shoots was $2.3 \mathrm{~cm}$ (Fig. 1a), and above $12 \%$ of them showed hyperhydricity (Fig. 2).

The number of shoots obtained in the presence of BA or ZEA in combination with IAA was also higher than in the presence of KIN or TDZ, when shoot tips of $T$. scorodonia were used as explants (Fig. 1b). However, the values for shoot tip cultures were slightly lower compared to those achieved from nodal explants on the media with the same growth regulators (Fig. 1a, b). The highest number of shoots from shoot tips occurred in the presence of $0.1 \mathrm{mg} \mathrm{L}^{-1}$ IAA and $2 \mathrm{mg} \mathrm{L}^{-1}$ BA (almost 7 shoots/explant) (Figs. 1b, 3a), followed by $2 \mathrm{mg} \mathrm{L}^{-1}$ ZEA (5.5 shoots/explant), $0.2 \mathrm{mg} \mathrm{L}^{-1} \mathrm{TDZ}$ (4 shoots/explant), and $2 \mathrm{mg} \mathrm{L}^{-1}$ KIN (3 shoots/explant). On the other hand, shoots cultured with optimal concentration of BA $\left(2 \mathrm{mg} \mathrm{L}^{-1}\right)$ and IAA $\left(0.1 \mathrm{mg} \mathrm{L}^{-1}\right)$ were about two-fold shorter than those grown with $0.2 \mathrm{mg} \mathrm{L}^{-1}$ BA (1.9 vs
$4 \mathrm{~cm}$ ), and $15 \%$ shorter $(1.9 \mathrm{~cm})$ than those grown with $2 \mathrm{mg} \mathrm{L}^{-1}$ ZEA and IAA $(2.2 \mathrm{~cm})$. Hyperhydricity of shoots (over $3 \%$ ) occurred only when shoot tips were cultured on the media supplemented with ZEA (Fig. 2). It is well known that higher concentrations of cytokinin promote shoot hyperhydricity in many plant species, for example Salvia przewalskii, Aloe polyphylla, Laburnum anagyroides, and Scutellaria alpina (Skała et al. 2007; Ivanova and van Staden 2008, 2011; Timofeeva et al. 2014; Grzegorczyk-Karolak et al. 2015). However, as it was observed in our study, the frequency of hyperhydric shoots in $T$. scorodonia culture did not evidently depend on cytokinin concentrations, but occurred more frequently when nodal segments were used as the explants. Also Fraga et al. (2004) reported that the type of explant was significantly related to hyperhydricity in regenerated shoots of Dianthus gratianopolitanus cultivar Frosty Fire. The authors observed that in the presence of NAA and BA in MS medium, the shoots proliferated from nodal explants were hyperhydrous in $40 \%$ of cases, whereas no hyperhydrous shoots were observed when shoot tips were used as explants under the same conditions (Fraga et al. 2004). The results described by the authors and these obtained in our study may be explained by differences in the concentration of endogenous cytokinins and their metabolism in various plant tissues, as well as the different water content in the explants used (Pospísilová et al. 2000; Kevers et al. 2004; Offord and Tyler 2009; Skała et al. 2015; Trifunović et al. 2015).

Based on the results presented in Fig. 1a, b, BA at concentration of $2 \mathrm{mg} \mathrm{L}^{-1}$ together with $0.1 \mathrm{mg} \mathrm{L}^{-1}$ IAA was considered the best combination for $T$. scorodonia axillary shoot multiplication from both shoot tips and nodal explants. BA at concentration of $6.6 \mu \mathrm{M}\left(1.5 \mathrm{mg} \mathrm{L}^{-1}\right)$ was also the best cytokinin for shoot formation from nodal segments of $T$. fruticans (Frabetti et al. 2009). However, the shoot multiplication rate (2.8 shoots/explant within 35 days) was considerably lower than the one achieved in our study. The poorest results in respect to shoot multiplication of T. scorodonia were obtained in the presence of KIN, despite the fact that this cytokinin appeared to be more effective than BA and TDZ for T. polium shoot multiplication (Al-Qudah et al. 2011).

Regardless of the composition of rooting medium (i.e. without growth regulators or with auxin), all the shoots formed roots within 42 days of culture (Fig. 4). This suggests that the endogenous concentration of auxins in the shoots was sufficient for root induction in hormone-free media as it was earlier reported by Piatczak and Wysokińska (2003) in Centaurium erythraea shoots. However, in our study the presence of auxin, its type and concentration affected the number of roots formed per shoot of $T$. 

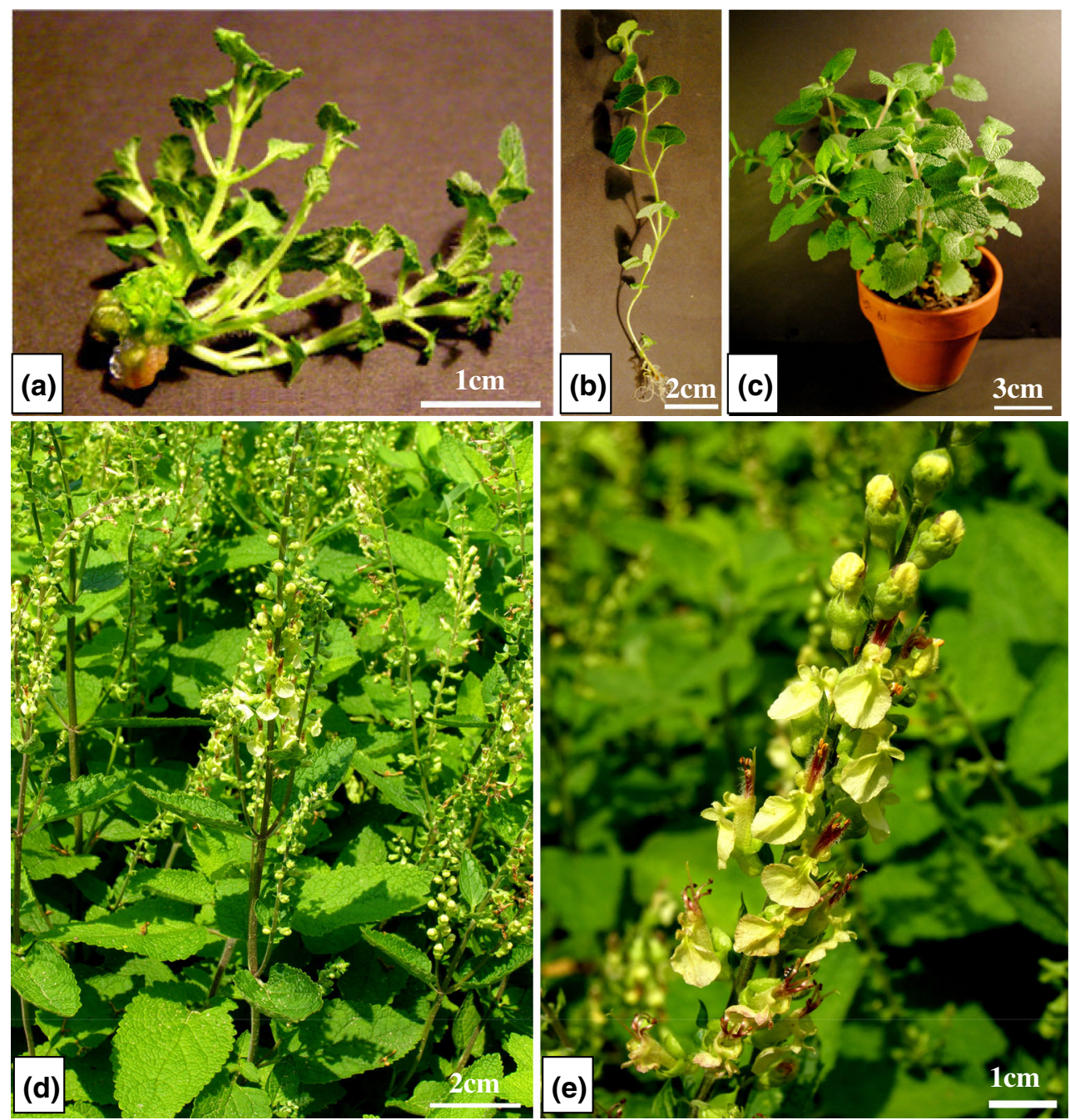

Fig. 3 In vitro micropropagation of $T$. scorodonia: a multiple shoot induction from shoot tip on MS medium supplemented with IAA $\left(0.1 \mathrm{mg} \mathrm{L}^{-1}\right)$ and BA $\left(2 \mathrm{mg} \mathrm{L}^{-1}\right)$; b rooted shoot on MS with IAA

(0.1 $\left.\mathrm{mg} \mathrm{L}^{-1}\right)$; c plant after 60 -day pot growth; $\mathbf{d}$ in vitro propagated plants grown in the field; $\mathbf{e}$ inflorescence in vitro-derived plant

Fig. 4 Effect of auxin on number of roots produced by shoots of $T$. scorodonia after 42 days of culture on MS medium. The values represent the means of three replicates. Means followed by the same letter were not significantly different at $P \leq 0.05$ according to the Kruskal-Wallis test

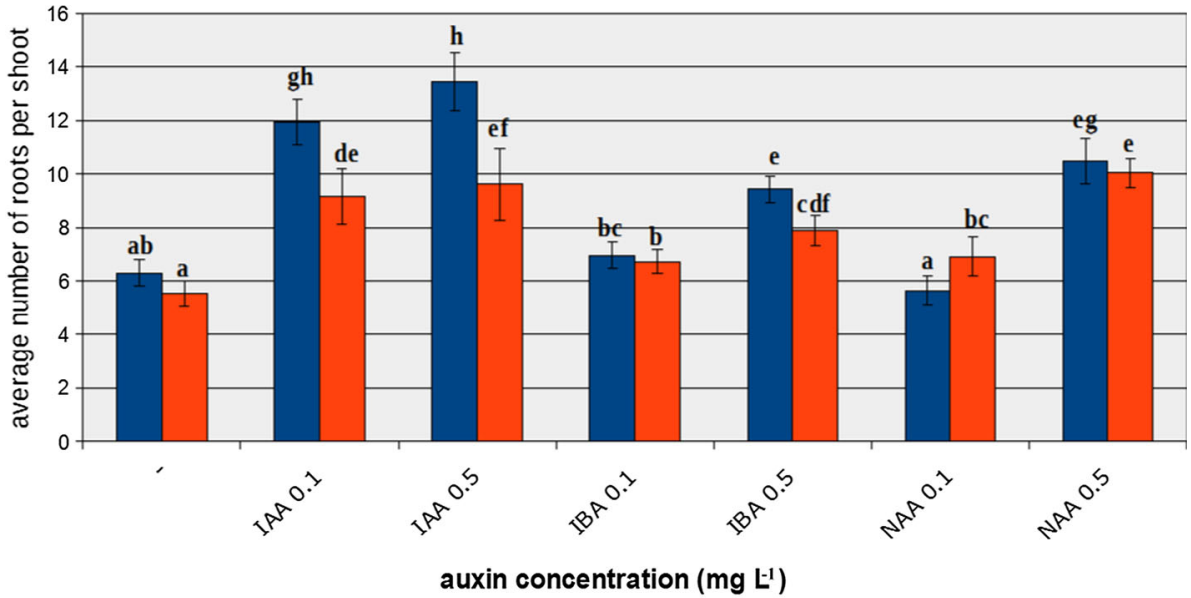

shoots derived from shoot-tips shoots derived from nodal explants 
scorodonia (Figs. 3b, 4). When the concentration of auxin in a medium increased from 0.1 to $0.5 \mathrm{mg} \mathrm{L}^{-1}$, the number of roots increased slightly in the presence of IAA and significantly in the presence of IBA or NAA. IAA appeared to be the most effective source of auxin for root formation of $T$. scorodonia. The highest number of roots per shoot was obtained when shoots were cultured with $0.5 \mathrm{mg} \mathrm{L}^{-1}$ IAA, resulting in about 13 roots from shoot tips and about 10 from nodal explants. For shoots derived from nodal explants, NAA at $0.5 \mathrm{mg} \mathrm{L}^{-1}$ was also efficient (about 10 roots per shoot). A study using in vitro-derived shoots of $T$. fruticans (Frabetti et al. 2009) and T. stocksianum (Bouhouche and Ksiksi 2007) and where IBA was used for rooting, found that the number of roots increased with increasing auxin concentrations $\left(0.01-2 \mathrm{mg} \mathrm{L}^{-1}\right)$. In contrast, in T. polium shoots, no root induction was observed in the presence of IBA or IAA $\left(0.1-2 \mathrm{mg} \mathrm{L}^{-1}\right)$ in the medium, and the best rooting was obtained when $0.8 \mathrm{mg} \mathrm{L}^{-1}$ of NAA was added (Al-Qudah et al. 2011). These results suggest that the effect of auxin depends on the species of Teucrium. In the present study, about $90 \%$ of T. scorodonia plants survived the acclimatization period when they were transferred to the greenhouse (Fig. 3c). The plants then grew to maturity in the field and achieved blooming and fruiting stage in the second year. The micropropagated plants (Fig. 3d,e) were phenotypically indistinguishable from their seed-derived counterparts.

\section{Genome size}

Flow cytometric analyses revealed that the nuclear DNA content ranged from 2.11 to $2.17 \mathrm{pg} / 2 \mathrm{C}$ and there was no significant difference between the genome size of plants obtained in vitro and seedlings (Table 1; Fig. 5). Only in the shoots grown on the MS medium supplemented with TDZ the DNA content was significantly higher; however, only by about $3 \%$ (Table 1 ).

The stability of DNA content has previously been found in in vitro-produced plants among other medicinal species, e.g. Oenothera paradoxa, Inula verbascifolia, Rubus chamaemorus, Solidago virgaurea, S. graminifolia, Plantago asiatica, and Eryngium planum (Sliwinska and Thiem 2007; Makowczyńska et al. 2008; Thiem et al. 2013). The present results confirmed that the proposed protocol guarantees in vitro production of plants with a stable genome size.

The genome size of $T$. scorodonia reported by Bennett and Smith (1991) was $2.4 \mathrm{pg} / 2 \mathrm{C}$. The difference between this value and the one established here is probably due to the different method (Feulgen densitometry) used previously.

\section{Composition of essential oils}

The hydrodistillation of aerial parts at flowering stage from in vitro and seed-derived plants resulted in an essential oil yield of $0.04 \%(\mathrm{v} / \mathrm{w})$ and $0.05 \%(\mathrm{v} / \mathrm{w})$, respectively, which was comparable to that of $T$. scorodonia plants growing in Italy $(0.03 \% \mathrm{w} / \mathrm{w})$ (Maccioni et al. 2007). Previous studies on other Teucrium species reported oil yields ranging from 0.05 to $1.5 \%$ (Djabou et al. 2013).

The chemical composition of essential oils with their relative amounts are listed in Table 2. Eighty-four compounds were identified, representing $96.3,95.9$, and $94.8 \%$ of the total oils from $\mathrm{V}_{1} \mathrm{P}, \mathrm{V}_{2} \mathrm{P}$, and SP samples, respectively. The chemical profiles of the oils were similar and the variation was mainly due to the concentration of individual components. The oils were characterized by high percentage of sesquiterpene hydrocarbons $\left(72.2 \%\right.$ in $\mathrm{V}_{1} \mathrm{P}$, $75.6 \%$ in $\mathrm{V}_{2} \mathrm{P}$, and $54.4 \%$ in $\mathrm{SP}$ ) such as: $\beta$-caryophyllene, germacrene $\mathrm{D}, \alpha$-humulene. The main component of the fraction was $\beta$-caryophyllene $(25.4,26$, and $22.3 \%$ in the oils from $\mathrm{V}_{1} \mathrm{P}, \mathrm{V}_{2} \mathrm{P}$, and $\mathrm{SP}$ samples, respectively). $\beta$ Caryophyllene was also the main essential oil component of T. scorodonia ssp. scorodonia from Italy (25.2\%) (Maccioni et al. 2007) and from 10 locations in Corsica (France) (17.3-25.2\%) (Djabou et al. 2012). Our results reveal a major difference between oils from in vitro- and
Table 1 Nuclear DNA content in leaves of $T$. scorodonia seedlings and in vitro derived shoots (cultured on MS medium with $0.1 \mathrm{mg} \mathrm{L}^{-1}$ IAA and cytokinin)

\begin{tabular}{lll}
\hline Plant material origin & Cytokinin (concentration in $\left.\mathrm{mg} \mathrm{L}^{-1}\right)$ & DNA content $(\mathrm{pg} / 2 \mathrm{C} \pm \mathrm{SE})$ \\
\hline Seedlings & & $2.118 \pm 0.012 \mathrm{a}$ \\
In vitro-derived shoots & & \\
From shoot tips & $0.2 \mathrm{BA}$ & $2.109 \pm 0.009 \mathrm{a}$ \\
& $0.5 \mathrm{BA}$ & $2.112 \pm 0.017 \mathrm{a}$ \\
& $0.5 \mathrm{KIN}$ & $2.128 \pm 0.008 \mathrm{ab}$ \\
& $0.05 \mathrm{TDZ}$ & $2.171 \pm 0.010 \mathrm{~b}$ \\
From nodal explants & $0.2 \mathrm{BA}$ & $2.109 \pm 0.005 \mathrm{a}$ \\
& $0.5 \mathrm{BA}$ & $2.109 \pm 0.008 \mathrm{a}$
\end{tabular}

Values followed by the same letters within a column are not significantly different $(P \leq 0.05)$ according to Tukey's test 
Fig. 5 Flow cytometric histograms of PI fluorescence intensity of the nuclei isolated from leaves of Vicia villosa (internal standard) and a Teucrium scorodonia seedling; b shoot derived from shoot tip grown in the presence of $0.5 \mathrm{mg} \mathrm{L}^{-1} \mathrm{BA}$ and $0.1 \mathrm{mg} \mathrm{L}^{-1}$ IAA or c $0.05 \mathrm{mg} \mathrm{L}^{-1} \mathrm{TDZ}$ and $0.1 \mathrm{mg} \mathrm{L}^{-1}$ IAA; $\mathbf{d}$ shoot derived from nodal explant grown in the presence of $0.2 \mathrm{mg} \mathrm{L}^{-1} \mathrm{BA}$ and $0.1 \mathrm{mg} \mathrm{L}^{-1}$ IAA. 1 - peak $\mathrm{G}_{1} /$ $\mathrm{G}_{0}$ of T. scorodonia, 2-peak $\mathrm{G}_{1} / \mathrm{G}_{0}$ of $V$. villosa

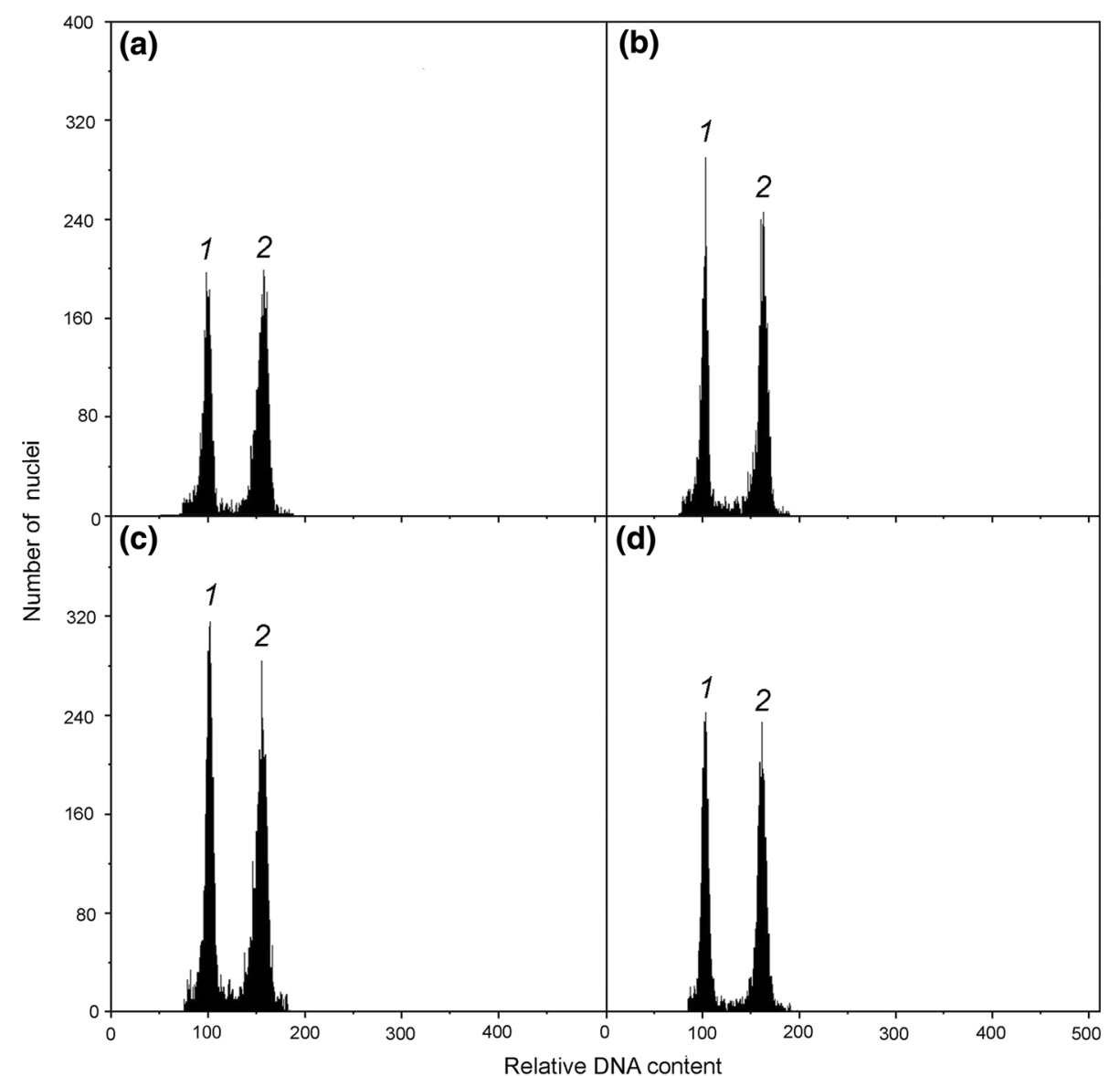

seed-derived plants of $T$. scorodonia regarding the content of germacrene $\mathrm{D}$ : in the oils of $\mathrm{V}_{1} \mathrm{P}$ and $\mathrm{V}_{2} \mathrm{P}$ samples the amount of the sesquiterpene (15.4 and $22.4 \%$ ) was almost 5 and 7 times higher than that found in the SP sample ( $3 \%$ ). The concentration of this compound was found to be $6.3 \%$ in essential oils isolated from aerial parts of $T$. scorodonia grown in Italy (Maccioni et al. 2007), and 4.6-10.1\% in Corsica (Djabou et al. 2012), which is higher than the seed-derived sample and lower than the in vitroderived samples found in the present experiment. The third sesquiterpene hydrocarbon, $\alpha$-humulene, was found to constitute $8.4-8.7 \%$ of the analyzed oils, which is similar to previous findings (Maccioni et al. 2007; Djabou et al. 2012). Other important sesquiterpene hydrocarbons such as $\alpha$ - and $\beta$-cubebene, $\alpha$-copaene, $\alpha$-gurjunene, $\delta$-cadinene were present in the SP sample in higher amounts than in the in vitro samples, with the exception of (E)- $\alpha$-bisabolene. Caryophyllene and humulene epoxides were significant components of all essential oils. However, another difference among the essential oils analyzed in the present study was that caryophyllene oxide, the main oxygenated sesquiterpene, was found to be higher in the SP (15.4\%) samples than the VP (6.2 and $3.9 \%)$ samples.
It is worth noting that in all essential oils, nine C13 compounds with the same carbon skeleton were identified as the products of carotenoid degradation: the hydrocarbon $\alpha$-ionene, the ketones (E)- $\beta$-ionone, (E)- $\beta$-damascone and (E)- $\beta$-damascenone and their derivatives, as well as oxides (theaspiranes and dihydroedulan). The total content of these components was low (2.7-3.0\%). Ionones and damascones have been found to occur in a wide range of essential oils but in small amounts. However, they significantly contributed to the fragrance of the oils (Sell 2010). Some compounds of this group were previously found in $T$. scorodonia essential oils (Djabou et al. 2012) and in essential oils of other Teucrium species (De Martino et al. 2012). All oils of $T$. scorodonia analyzed here were poor in monoterpenes both hydrocarbons (1.1-1.9\%) and oxygenated compounds $(2.2-2.3 \%)$.

A comparative analysis of essential oils from micropropagated plants and their seed-derived counterparts was previously performed on some other species and numerous differences in yields and oil profiles were recorded. For example, the yield of essential oils isolated from Salvia sclarea plants, derived in vitro from shoot tips, was $0.1 \%$, while plants propagated from seeds produced $0.2 \%$ of 
Table 2 Constituents of essential oils from in vivo/ in vitro Teucrium scorodonia plants

\begin{tabular}{|c|c|c|c|c|c|c|}
\hline Peak number & Compound & RI & $\mathrm{RI}_{\text {lit }}$ & $\mathrm{SP}(\%)$ & $\mathrm{V}_{1} \mathrm{P}(\%)$ & $\mathrm{V}_{2} \mathrm{P}(\%)$ \\
\hline 1 & $\alpha$-Pinene & 930 & 934 & $\mathrm{t}$ & $\mathrm{t}$ & 0.1 \\
\hline 2 & Oct-1-en-3-one & 956 & 956 & - & - & $\mathrm{t}$ \\
\hline 3 & Octane-2,3-dione & 961 & 959 & $\mathrm{t}$ & $\mathrm{t}$ & 0.1 \\
\hline 4 & Oct-1-en-3-ol & 964 & 966 & 4.4 & 3.0 & 4.3 \\
\hline 5 & $\beta$-Pinene & 969 & 974 & $\mathrm{t}$ & - & 0.1 \\
\hline 6 & 2-Pentylfuran & 978 & 977 & 0.1 & 0.1 & $\mathrm{t}$ \\
\hline 7 & Myrcene & 982 & 983 & 0.2 & 0.1 & 0.2 \\
\hline 8 & Car-3-ene & 1004 & 1006 & - & - & 0.1 \\
\hline 9 & Phenylacetaldehyde & 1008 & 1012 & - & $\mathrm{t}$ & 0.1 \\
\hline 10 & p-Cymene & 1011 & 1015 & 0.1 & 0.1 & $\mathrm{t}$ \\
\hline 11 & Limonene & 1020 & 1025 & 0.6 & 0.2 & 0.6 \\
\hline 12 & $(Z)$ - $\beta$-Ocimene & 1027 & 1029 & 0.1 & 0.3 & 0.3 \\
\hline 13 & $(E)$ - $\beta$-Ocimene & 1038 & 1041 & 0.1 & 0.2 & 0.2 \\
\hline 14 & $\gamma$-Terpinene & 1048 & 1051 & 0.1 & 0.1 & $\mathrm{t}$ \\
\hline 15 & cis-Linalool oxide (furanoid) & 1073 & 1072 & $\mathrm{t}$ & $\mathrm{t}$ & $\mathrm{t}$ \\
\hline 16 & Terpinolene & 1078 & 1082 & 0.3 & 0.1 & 0.3 \\
\hline 17 & Linalool & 1084 & 1086 & 1.8 & 1.9 & 1.7 \\
\hline 18 & Oct-1-en-3-yl acetate & 1093 & 1093 & 0 & 0.1 & 0.2 \\
\hline 19 & Oct-3-yl acetate & 1108 & 1110 & 0 & 0.1 & 0.2 \\
\hline 20 & allo-Ocimene & 1118 & 1117 & $\mathrm{t}$ & $\mathrm{t}$ & $\mathrm{t}$ \\
\hline 21 & 2-Methylbenzofuran & 1147 & 1149 & 0.3 & 0.3 & $\mathrm{t}$ \\
\hline 22 & Terpinen-4-ol & 1160 & 1164 & 0.2 & 0.1 & 0.1 \\
\hline 23 & Methyl salicylate & 1168 & 1171 & $\mathrm{t}$ & 0.1 & 0.2 \\
\hline 24 & $\alpha$-Terpineol & 1171 & 1176 & 0.1 & $\mathrm{t}$ & 0.1 \\
\hline 25 & $\beta$-Cyclocitral & 1195 & 1196 & 0.1 & 0.2 & 0.1 \\
\hline 26 & $\alpha$-Ionene & 1243 & 1240 & 0.3 & 0.4 & 0.2 \\
\hline 27 & Dihydroedulan & 1288 & 1290 & $\mathrm{t}$ & $\mathrm{t}$ & $\mathrm{t}$ \\
\hline 28 & Theaspirane A & 1290 & 1293 & $\mathrm{t}$ & $\mathrm{t}$ & 0.1 \\
\hline 29 & Theaspirane B & 1304 & 1304 & $\mathrm{t}$ & $\mathrm{t}$ & 0.1 \\
\hline 30 & 1,1,5,6-Tetramethylindane & 1308 & 1311 & 0.1 & 0.1 & $\mathrm{t}$ \\
\hline 31 & Bicycloelemene & 1333 & 1340 & 0.1 & 0.4 & 0.6 \\
\hline 32 & Neryl acetate & 1340 & 1342 & $\mathrm{t}$ & $\mathrm{t}$ & 0.1 \\
\hline 33 & $\alpha$-Cubebene & 1350 & 1354 & 5.3 & 3.0 & 3.0 \\
\hline 34 & Geranyl acetate & 1358 & 1362 & $\mathrm{t}$ & $\mathrm{t}$ & 0.2 \\
\hline 35 & $(E)$ - $\beta$-Damascenone & 1360 & 1363 & 0.2 & 0.3 & 0.3 \\
\hline 36 & $\alpha$-Ylangene & 1371 & 1376 & 0.2 & 0.5 & 0.4 \\
\hline 37 & $\alpha$-Copaene & 1375 & 1379 & 2.2 & 1.3 & 1.0 \\
\hline 38 & $\beta$-Bourbonene & 1382 & 1386 & 0.8 & 1.1 & 0.8 \\
\hline 39 & $\beta$-Cubebene & 1385 & 1390 & 2.5 & 1.7 & 1.7 \\
\hline 40 & $(E)$ - $\beta$-Damascone & 1394 & 1398 & 0.1 & 0.1 & 0.1 \\
\hline 41 & 7,8-Dihydro- $\beta$-damascenone & 1397 & -* & 1.3 & 1.3 & 1.1 \\
\hline 42 & $\alpha$-Gurjunene & 1409 & 1413 & 1.3 & 1.0 & 1.1 \\
\hline 43 & $\beta$-Caryophyllene & 1421 & 1420 & 22.3 & 25.4 & 26.0 \\
\hline 44 & $\beta$-Copaene & 1426 & 1430 & 0.3 & 2.1 & 1.3 \\
\hline 45 & trans- $\alpha$-Bergamotene & 1431 & 1434 & 0.1 & 0.1 & 0.1 \\
\hline 46 & Aromadendrene & 1440 & 1443 & 0.2 & 0.2 & 0.3 \\
\hline 47 & (E)- $\beta$-Farnesene & 1446 & 1446 & 0.7 & 1.5 & 0.2 \\
\hline 48 & $\alpha$-Humulene & 1452 & 1455 & 8.4 & 8.7 & 8.7 \\
\hline
\end{tabular}


Table 2 continued

\begin{tabular}{|c|c|c|c|c|c|c|}
\hline Peak number & Compound & RI & $\mathrm{RI}_{\text {lit }}$ & $\mathrm{SP}(\%)$ & $\mathrm{V}_{1} \mathrm{P}(\%)$ & $\mathrm{V}_{2} \mathrm{P}(\%)$ \\
\hline 49 & $\alpha$-Cadinene & 1457 & 1459 & 0.6 & 1.2 & 1.2 \\
\hline 50 & $\beta$-Ionone-5,6-epoxide & 1460 & 1460 & 0.7 & $\mathrm{t}$ & 0.1 \\
\hline 51 & $(E)$ - $\beta$-Ionone & 1463 & 1467 & 0.4 & 0.8 & 0.7 \\
\hline 52 & $\gamma$-Muurolene & 1472 & 1474 & 0.4 & 0.5 & 0.3 \\
\hline 53 & Germacrene D & 1479 & 1479 & 3.0 & 15.4 & 22.4 \\
\hline 54 & $(3 Z, 6 E)$ - $\alpha$-Farnesene & 1481 & 1480 & 0.3 & 0.8 & $\mathrm{t}$ \\
\hline 55 & 4-epi-Cubebol & 1486 & 1490 & 0.7 & 0.7 & 0.6 \\
\hline 56 & Bicyclogermacrene & 1491 & 1494 & 0.6 & 1.5 & 2.0 \\
\hline 57 & $(3 E, 6 E)-\alpha$-Farnesene & 1493 & 1498 & 0.2 & 0.6 & 0.6 \\
\hline 58 & $\beta$-Bisabolene & 1499 & 1503 & 0.5 & 0.7 & 0.5 \\
\hline 59 & $\gamma$-Cadinene & 1505 & 1512 & 0.5 & 0.6 & 0.5 \\
\hline 60 & trans-Calamenene & 1508 & 1514 & 0.3 & 0.1 & $\mathrm{t}$ \\
\hline 61 & $\delta$-Cadinene & 1513 & 1516 & 1.5 & 1.2 & 1.3 \\
\hline 62 & Cadina-1,4-diene & 1523 & 1523 & 0.2 & 0.2 & 0.1 \\
\hline 63 & $(E)$ - $\alpha$-Bisabolene & 1531 & 1530 & 1.4 & 1.9 & 1.5 \\
\hline 64 & $\beta$-Caryophyllene oxide & 1539 & 1546 & 1.4 & 0.8 & 0.2 \\
\hline 65 & $\beta$-Calacorene & 1545 & 1541 & 0.2 & 0.2 & $\mathrm{t}$ \\
\hline 66 & Germacrene B & 1550 & 1552 & 0.3 & 0.3 & $\mathrm{t}$ \\
\hline 67 & Spathulenol & 1564 & 1569 & 2.2 & 0.8 & 0.7 \\
\hline 68 & Caryophyllene oxide & 1570 & 1573 & 15.4 & 6.2 & 3.9 \\
\hline 69 & Salvial-4(14)-en-1-one & 1577 & 1584 & 0.3 & 0.5 & $\mathrm{t}$ \\
\hline 70 & Humulene epoxide 1 & 1582 & 1587 & 0.4 & 0.3 & 0.1 \\
\hline 71 & Humulene epoxide 2 & 1593 & 1597 & 4.4 & 1.8 & 1.3 \\
\hline 72 & Torilenol & 1599 & 1601 & 0.3 & 0.2 & $\mathrm{t}$ \\
\hline 73 & 1-epi-Cubenol & 1613 & 1619 & 0.6 & 0.2 & 0.1 \\
\hline 74 & Humulene epoxide 3 & 1618 & 1624 & $\mathrm{t}$ & $\mathrm{t}$ & $\mathrm{t}$ \\
\hline 75 & Caryophylla-4(14),8(15)-dien-5 $\alpha$-ol & 1620 & 1626 & 0.2 & $\mathrm{t}$ & 0.1 \\
\hline 76 & T-Muurolol & 1625 & 1632 & 1.7 & 1.1 & 0.6 \\
\hline 77 & T-Cadinol & 1627 & 1633 & 0.3 & 0.6 & 0.1 \\
\hline 78 & Cubenol & 1630 & 1636 & 0.2 & 0.2 & 0.1 \\
\hline 79 & $\alpha$-Cadinol & 1637 & 1642 & 0.6 & 0.7 & 0.6 \\
\hline 80 & Phenantrene & 1747 & 1744 & 0.1 & $\mathrm{t}$ & 0.1 \\
\hline 81 & Farnesylacetone & 1888 & 1895 & - & 0.2 & 0.2 \\
\hline 82 & Phytol & 2099 & 2099 & $\mathrm{t}$ & - & 1.3 \\
\hline 83 & Pentacosane & 2500 & 2500 & - & $\mathrm{t}$ & 0.1 \\
\hline \multirow[t]{8}{*}{84} & Heptacosane & 2700 & 2700 & - & - & 0.1 \\
\hline & Total identified & & & 94.8 & 96.3 & 95.9 \\
\hline & Sesquiterpene hydrocarbons & & & 54.4 & 72.2 & 75.6 \\
\hline & Oxygenated sesquiterpenes & & & 28.7 & 14.1 & 8.4 \\
\hline & Monoterpene hydrocarbons & & & 1.5 & 1.1 & 1.9 \\
\hline & Oxygenated monoterpenes & & & 2.2 & 2.2 & 2.3 \\
\hline & C13 compounds & & & 3.0 & 2.9 & 2.7 \\
\hline & Others & & & 5.0 & 3.8 & 5.0 \\
\hline
\end{tabular}

The concentrations of the main compounds were signified in bold

$R I$ relative retention index on Rtx-1 ms column, $R I_{l i t}$ relative retention index of literature, $S P$ essential oil from in vivo plants, $V_{1} P$ and $V_{2} P$ essential oils from in vitro plants derived from shoots cultured on MS medium with either $0.1 \mathrm{mg} \mathrm{L}^{-1}$ IAA and $0.2 \mathrm{mg} \mathrm{L}^{-1} \mathrm{BA}$, or $0.1 \mathrm{mg} \mathrm{L}^{-1} \mathrm{IAA}$ and $0.5 \mathrm{mg} \mathrm{L}^{-1} \mathrm{KIN}$ $t=\operatorname{traces}(<0.05 \%)$

* Unavailable data 
essential oils (Kuźma et al. 2009). The same tendency was observed for species of S. przewalskii (Skała et al. 2007) and T. polium (Al-Qudah et al. 2011). Also qualitative differences in oil composition of in vitro- and in vivo-derived plants of S. przewalskii were reported by Skała et al. (2007). The authors implied that those differences could be due to the conditions of in vitro cultures, especially the presence of plant growth regulators. Al-Qudah et al. (2011) reported that the presence of BA and NAA in the culture medium affected $\beta$-caryophyllene level in oil isolated from in vitro regenerated plants of $T$. polium. No $\beta$-caryophyllene was found in the in vitro sample that was grown on MS medium without plant growth regulators. Affonso et al. (2009) reported that in vitro shoot culture of Thymus vulgaris differed in essential oil composition depending on the plant hormones in the media. Amoo et al. (2012) conclude that the effect of growth regulators may be reduced during long-term ex vitro cultivation. This may be the reason why our findings revealed that field-grown micropropagated and seed-derived T. scorodonia were similar in respect to essential oil content and composition. Similarly, only small differences were detected in the contents of essential oil components between grown ex vitro and in vitro plants of four Solidago species (Kalemba and Thiem 2004).

In conclusion, our study provides the first demonstration of an efficient micropropagation procedure for T. scorodonia. Shoot tips and nodal explants were used as good starting material for axillary shoot multiplication. Multiple shoots possessed the same nuclear DNA content as seedlings, except when they were grown on the medium supplemented with TDZ. After three cycles on optimized multiplication medium ( 35 days each) and three cycles on rooting medium (42 days each) it was possible to obtain about 300 and 400 plants from a single shoot tip and nodal explant, respectively. The present results also show that in vitro-derived plants of $T$. scorodonia can be used as a potential source of essential oils whose main components are $\beta$-caryophyllene and germacrene $\mathrm{D}$. The developed procedure appeared to be suitable for sustainable production of plants for pharmaceutical use.

\begin{abstract}
Author contribution This research was accomplished with the collaboration of all authors. JM performed the micropropagation experiments, evaluated results, took photographic documentation, performed statistical analyses, prepared samples for essential oil analysis and wrote the manuscript. ES performed flow cytometric determination of DNA contents, evaluated the results, and participated in writing the manuscript. DK performed GC-MS analyses and wrote part of the manuscript. EP and HW were responsible for verification of the paper.
\end{abstract}

\section{Compliance with ethical standards}

Conflict of interest The authors declare that they have no conflict of interest.
Open Access This article is distributed under the terms of the Creative Commons Attribution 4.0 International License (http://crea tivecommons.org/licenses/by/4.0/), which permits unrestricted use, distribution, and reproduction in any medium, provided you give appropriate credit to the original author(s) and the source, provide a link to the Creative Commons license, and indicate if changes were made.

\section{References}

Adams RP (2002) Identification of essential oil components by Gas Chromatography/Mass Spectroscopy. Allured, Carol Stream, IL Affonso VR, Bizzo HR, Lage CLS, Sato A (2009) Influence of growth regulators in biomass production and volatile profile of in vitro plantles of Thymus vulgaris L. J Agric Food Chem 57:6392-6395. doi:10.1021/jf900816c

Al-Qudah T, Shibli RA, Alali FQ (2011) In vitro propagation and secondary metabolites production in wild germander (Teucrium polium L.). In Vitro Cell Dev Biol Plant 47:496-505. doi:10. 1007/s11627-011-9352-9

Amoo SO, Aremu AO, Van Staden J (2012) In vitro plant regeneration, secondary metabolite production and antioxidant activity of micropropagated Aloe arborescens Mill. Plant Cell Tiss Organ Cult 111:345-358. doi:10.1007/s11240-012-0200-3

Bahi A, Al Mansouri S, Al Memari E, Al Ameri M, Nurulain SM, Ojha S (2014) $\beta$-Caryophyllene a CB2 receptor agonist produces multiple behavioral changes relevant to anxiety and depression in mice. Physiol Behav 135:119-124. doi:10.1016/j.physbeh. 2014.06.003

Bairu MW, Aremu AO, Van Staden J (2011) Somaclonal variation in plants: causes and detection methods. Plant Growth Regul 63:147-173. doi:10.1007/s10725-010-9554-x

Bennett MD, Smith JB (1991) Nuclear DNA amounts in angiosperms. Philos Trans R Soc Lond B Biol Sci 334:309-345

Bouhouche N, Ksiksi T (2007) An efficient in vitro plant regeneration system for the medicinal plant Teucrium stocksianum Boiss. Plant Biotechnol Rep 1:179-184. doi:10.1007/s11816-007-0033-4

De Martino L, Mancini E, Marandino A, de Almeida LFR, de Feo V (2012) Chemistry and antigerminative activity of essential oils and monoterpenoids from Mediterranean plants. Curr Bioactive Comp 8:13-49. doi:10.2174/157340712799828179

Djabou N, Allali H, Battesti MJ, Tabti B, Costa J, Muselli A, Varesi L (2012) Chemical and genetic differentiation of two Mediterranean subspecies of Teucrium scorodonia L. Phytochemistry 74:123-132. doi:10.1016/j.phytochem.2011.09.002

Djabou N, Lorenzi V, Guinoiseau E, Andreani S, Giuliani M-C, Desjobert J-M, Bolla J-M, Costa J, Berti L, Luciani A, Muselli A (2013) Phytochemical composition of Corsican Teucrium essential oils and antibacterial activity against foodborne or toxiinfectious pathogens. Food Control 30:354-363. doi:10.1016/j. foodcont.2012.06.025

Dzialuk A, Chybicki I, Welc M, Sliwinska E, Burczyk J (2007) Presence of triploids among oak species. Ann Bot 99:959-964. doi: $10.1093 / \mathrm{aob} / \mathrm{mcm} 043$

European Pharmacopoeia 5th edn. (2005) Council of Europe: Edqm; 2.812, pp 217-218

Frabetti M, Gutiérrez-Pesce P, Mendoza-de Gyves E, Rugini E (2009) Micropropagation of Teucrium fruticans L., an ornamental and medicinal plant. In Vitro Cell Dev Biol Plant 45:129-134. doi:10.1007/s11627-009-9192-z

Fraga M, Alonso M, Ellul Ph, Borja M (2004) Micropropagation of Dianthus gratianopolitanus. Hort. Science 39:1083-1087 
Galbraith DW, Harkins KR, Maddox JR, Ayres NM, Sharma DP, Firoozabady E (1983) Rapid flow cytometric analysis of the cell cycle in intact plant tissues. Science 220:1049-1051

Grzegorczyk-Karolak I, Kuźma Ł, Wysokińska H (2015) The effect of cytokinins on shoot proliferaion, secondary metabolite production and antioxidant potential in shoot cultures od Scutellaria alpina. Plant Cell Tiss Organ Cult 122:699-708. doi:10.1007/s11240-015-0804-5

Guimarães-Santos A, Santos DS, Santos IR, Lima RR, Pereira A, de Moura LS, Carvalho RN Jr, Lameira O, Gomes-Leal W (2012) Copaiba oil-resin treatment is neuroprotective and reduces neutrophil recruitment and microglia activation after motor cortex excitotoxic injury. Evid Based Complement Alternat Med. doi:10.1155/2012/918174

Ivanova M, van Staden J (2008) Effect of ammonium ions and cytokinins on hyperhydricity and multiplication rate of in vitro regenerated shoots of Aloe polyphylla. Plant Cell Tiss Organ Cult 92:227-231. doi:10.1007/s11240-007-9311-7

Ivanova M, van Staden J (2011) Influence of gelling agent and cytokinins on the control of hyperhydricity in Aloe polyphylla. Plant Cell Tiss Organ Cult 104:13-21. doi:10.1007/s11240-0109794-5

Kalemba D, Thiem B (2004) Constituents of the essential oils of four micropropagated Solidago species. Flavour Fragr J 19:40-43. doi:10.1002/ffj.1271

Kevers C, Frank T, Strasser RJ, Dommes J, Gaspar T (2004) Hyperhydricity of micropropagated shoots: a typically stressinduced change of physiological state. Plant Cell Tiss Organ Cult 77:181-191. doi:10.1023/B:TICU.0000016825.18930.e4

Kovacevic NN, Lakusic BS, Ristic MS (2001) Composition of the essential oil of seven Teucrium species from Serbia and Montenegro. J Essent Oil Res 13:163-165. doi:10.1080/ 10412905.2001.9699649

Küçük M, Güleç C, Yaşar A, Üçüncü O, Yayli N, Coşkunçelebi K, Terzioğlu S, Yayli N (2008) Chemical composition and antimicrobial activities of the essential oils of Teucrium chamaedrys subsp. chamaedrys, $T$. orientale var. puberulens and $T$. chamaedrys subsp. lydium. Pharm Biol 44:592-599. doi:10. 1080/13880200600896868

Kuźma Ł, Kalemba D, Różalski M, Różalska B, Więckowska-Szakiel M, Krajewska U, Wysokińska H (2009) Chemical composition and biological activities of essential oil from Salvia sclarea plants regenerated in vitro. Molecules 14:1438-1447. doi:10. 3390/molecules14041438

Lebedev V, Shestibratov K (2016) Larg-scale micropropagation of common ash. Biotechnol 15:1-9. doi:10.3923/biotech.2016.1.9

Leite NF, Sobral-Souza CE, Albuquerque RS, Brito DIV, Lavor AKLS, Alencar LBB, Tintino SR, Ferreira JVA, Figueredo FG, Lima LF (2013) In vitro cytotoxic and antiparasitic activity of caryophyllene and eugenol against Trypanosoma cruzi and Leishmania brasiliensis. Rev Cubana Plant Med 18:522-528

Maccioni S, Baldini R, Tebano M, Cioni PL, Flamini G (2007) Essential oil of Teucrium scorodonia L. ssp. scorodonia from Italy. Food Chem 104:1393-1395. doi:10.1016/j.foodchem. 2007.01.070

Makowczyńska J, Andrzejewska-Golec E, Sliwinska E (2008) Nuclear DNA content in different plant material of Plantago asiatica L. cultured in vitro. Plant Cell Tiss Organ Cult 94:65-71. doi:10.1007/s11240-008-9387-8

Marco JL, Rodriquez B, Savona G, Piozzi F (1982) Diterpenoids from Teucrium scorodonia, three neo-clerodane derivatives. Phytochemistry 21:2567-2569. doi:10.1016/00319422(82)85258-8

Marco JL, Rodriquez B, Pascual C, Savona G, Piozzi F (1983) Teuscorodin, teuscorodonin and 2-hydroxyteuscorolide, neo- clerodane diterpenoids from Teucrium scorodonia. Phytochemistry 22:727-731. doi:10.1016/S0031-9422(00)86971-X

Matsuda S, Sato M, Ohno S, Yang SJ, Doi M, Hosokawa M (2014) Cutting leaves and plant growth regulator application enhance somaclonal variation induced by transposition of VGs1 of Saintpaulia. J Jpn Soc Hortic Sci 83:308-316. doi:10.2503/ jjshs1.MI-009

Mirek Z, Piękoś-Mirkowa H, Zając A, Zając M (2002) Flowering plants and pteridophytes of Poland a checklist. Biodiversity of Poland. Inst. Bot. Polish Academy of Sciences, Kraków, p 176

Murashige T, Skoog F (1962) A revised medium for rapid growth and bio assays with tobacco tissue cultures. Physiol Plant 15:473-497. doi:10.1111/j.1399-3054.1962.tb08052.x

Noge K, Becerra JX (2009) Germacrene D, a common sesquiterpene in the genus Bursea (Burseaceae). Molecules 14:5289-5297. doi:10.3390/molecules14125289

Offord A, Tyler JL (2009) In vitro propagation of Pimelea spicata R.Br (Thymelaeaceae), an endangered species of the Sydney region, Australia. Plant Cell Tiss Organ Cult 98:19-23. doi:10. 1007/s11240-009-9534-x

Oksman-Caldentey KM (2014) Somaclonal variation in Solanaceous medicinal plants. In: Jain SM, Brar DS, Ahloowalia BS (eds) Somaclonal variation and induced mutations in crop improvement, 3rd edn. Springer, New York, pp 233-252

Piątczak E, Wysokińska H (2003) In vitro regeneration of Centaurium erthraea Rafn from shoot tips and other seedling explants. Acta Soc Bot Pol 72:283-288

Picaud S, Olsson ME, Brodelius M, Brodelius PE (2006) Cloning, expression, purification and characterization of recombinant (+)germacrene D synthase from Zingiber officinale. Arch Biochem Biophys 452:17-28. doi:10.1016/j.abb.2006.06.007

Pospíšilová J, Synková H, Rulcová J (2000) Cytokinins and water stress. Biol Plant 43:321-328. doi:10.1023/A:1026754404857

Rodriguez-Hanh L, Esquivel B, Cardenas J (1994) Clerodane diterpenes in Labiatae. In: Herz W, Kirby GW, Moore RE, Steglich W, Tamm Ch (eds) Progress in the chemistry of organic natural products, vol 63, 1st edn. Springer, New York, pp 107-184. doi:10.1007/978-3-7091-9281-8

Sell C (2010) Chemistry of essential oils. In: Baser KHC, Buchbauer G (eds) Handbook of essential oils, Science, technology and applications. CRS Press, Boca Raton, pp 121-150

Skała S, Kalemba D, Wajs A, Różalski M, Krajewska U, Różalska B, Więckowska-Szakiel M, Wysokińska H (2007) In vitro propagation and chemical and biological studies of the essential oil of Salvia przewalskii Maxim. Z Naturforsch 62:839-848

Skała S, Grąbkowska R, Sitarek P, Kuźma Ł, Błauż A, Wysokińska H (2015) Rhaponticum carthamoides regeneration through direct and indirect organogenesis, molecular profiles and secondary metabolite production. Plant Cell Tiss Organ Cult 123:83-98. doi:10.1007/s11240-015-0816-1

Sliwinska E, Thiem B (2007) Genome size stability in six medicinal plant species propagated in vitro. Biol Plant 51:556-558

Thiem B, Sliwinska E (2003) Flow cytometric analysis of nuclear DNA content in cloudberry (Rubus chamaemorus L.) in vitro cultures. Plant Sci 164:129-134. doi:10.1016/S01689452(02)00344-8

Thiem B, Kikowska M, Krawczyk A, Więckowska B, Sliwinska E (2013) Phenolic acid and DNA contents of micropropagated Eryngium planum L. Plant Cell Tiss Organ Cult 114:197-206. doi:10.1007/s11240-013-0315-1

Timofeeva SN, Elkonin LA, Tyrnov VS (2014) Micropropagation of Laburnum anagyroides Medic. throught axillary shoot regeneration. In Vitro Cell Dev Biol Plant 50:561-567 
Trifunović M, Motyka V, Cingel A, Subotić A, Jevremović S, Petrić M, Holik J, Malbeck J, Dobrev PI, Dragićević IĆ (2015) Changes in cytokinin content and altered cytokinin homeostasis in AtCKX1 and AtCKX2-overexpressing centaury (Centaurium erythraea Rafn.) plants grown in vitro. Plant Cell Tiss Organ Cult 120:767-777. doi:10.1007/s11240-014-0646-6

Tutin TG, Heywood VH, Burges NA, Moore DM, Valentine DH, Walters SM, Webb DA (1972) Flora Europaea, vol 3. Cambridge University Press, Cambridge, pp 129-151

Ulubelen A, Topu G, Sönmez U (2000) Chemical and biological evaluation of genus Teucrium. Stud Nat Prod Chem 23:591-648. doi:10.1016/S1572-5995(00)80139-8
Valant-Vetschera KM, Roitman JN, Wollenweber E (2003) Chemodiversity of exudates flavonoids in some members of the Lamiaceae. Biochem Syst Ecol 31:1279-1289. doi:10.1016/ S0305-1978(03)00184-4

Zarai Z, Kadri A, Ben Chobba I, Ben Mansour R, Bekir A, Mejdoub H, Gharsallah N (2011) The in vitro evaluation of antibacterial, antifungal and cytotoxic properties of Marrubium vulgare L. essential oil grown in Tunisia. Lipids Health Dis 10:161-168. doi:10.1186/1476-511X-10-161 